\title{
Trophic interactions among sympatric zooplanktivorous fish species in volume change conditions in a large, shallow, tropical lake
}

\author{
Rodrigo Moncayo-Estrada ${ }^{1}$, Owen T. Lind ${ }^{2}$ and Carlos Escalera-Gallardo ${ }^{1}$
}

Significant reductions in the water volume of shallow lakes impose a restriction on species segregation promoting more interactions in the trophic relationships. The diets of three closely related zooplanktivorous silversides belonging to the Atherinopsidae species flock of lake Chapala, Mexico, were analyzed at two sites (Chirostoma jordani, C. labarcae, and C. consocium). Diets were described in critical shallow (August 2000) and volume recovery conditions (August 2005). Diets included mainly cladocerans (Bosmina, Ceriodaphnia, and Daphnia) and copepods (Cyclops). A significant difference in diets was detected when comparing years (MRPP analysis, $A=0.22, \mathrm{p}<0.0001$ ) and sites at different years (MRPP analysis, A $=0.17, \mathrm{p}=0.004)$. According to niche breadth mean values, species were classified as specialized and intermediate feeders. In shallow conditions, the small range of niche breadth (1.72 to 3.64) and high diet overlap values $(\mathrm{D}=0.64, \mathrm{~L}=8.62)$ indicated a high potential for interspecific exploitative interaction. When the lake volume recovered, an increase in the niche breadth range (1.04 to 4.96) and low niche overlap values $(\mathrm{D}=0.53, \mathrm{~L}=2.32)$ indicated a reduction of the species interaction. The MannWhitney $U$-test supported this pattern by showing a significant difference between years for niche overlap $(\mathrm{p}=0.006)$. The increased interaction during the low volume suggests alternative segregation in life-history variations and other niche dimensions such as spatial or temporal distribution.

La reducción significativa en el volumen de agua de los lagos someros impone una restricción en la segregación de las especies y promueve una mayor interacción en las relaciones tróficas. Se analizó la dieta de tres especies cercanamente emparentadas de zooplanctívoros pertenecientes al flock de Aterinópsidos del lago de Chapala en dos sitios (Chirostoma jordani, C. labarcae y C. consocium). Las dieta fue descrita en una condición somera crítica (Agosto 2000) y en una condición de recuperación del lago (Agosto 2005). En la dieta se incluyen principalmente cladóceros (Bosmina, Ceriodaphnia y Daphnia) y copépodos (Cyclops). Se detectó una diferencia significativa en la dieta cuando se comparan los años (análisis MRPP, $\mathrm{A}=0.22, \mathrm{p}<0.0001$ ) y los sitios en los diferentes años (análisis MRPP, $\mathrm{A}=0.17, \mathrm{p}=0.004$ ). De acuerdo a los valores promedio de amplitud de nicho, las especies fueron clasificadas como especialistas y consumidores intermediarios. En condiciones someras, el pequeño intervalo de la amplitud de nicho (1.72 a 3.64) y los altos valores del traslape de nicho $(\mathrm{D}=0.64, \mathrm{~L}=8.62)$ indicaron un alto potencial para una interacción explotativa inter-específica. Cuando el lago se recupera en su volumen, un incremento en el intervalo de amplitud de nicho $(1.04$ a 4.96) y los bajos valores del traslape de nicho $(\mathrm{D}=0.53, \mathrm{~L}=2.32)$ indicaron una reducción en la interacción de las especies. La prueba $U$ de Mann-Whitney refuerza este patrón al mostrar una diferencia significativa entre los años para el traslape de nicho $(\mathrm{p}=0.006)$. El incremento en la interacción de las especies durante condiciones de volumen bajo, sugiere una segregación alternativa con variaciones en la historia de vida y en otras dimensiones del nicho como en el caso de la distribución espacial y temporal.

Key words: Niche breadth, Silversides, Segregation, Water-level fluctuation.

\section{Introduction}

The study of diet interactions in ecological studies helps address questions such as the niche partitioning among closely related species (Richards et al., 2000; Carvalho \& Gomes, 2004), provides key elements in understanding the predator and prey relationships (Liao et al., 2002) and enables modeling the effect of environmental changes on an aquatic community's trophic interactions (Kuroda et al., 2005).
Trophic relationships among fish species comprising feeding guilds have been examined in different aquatic ecosystems (Emery, 1973; Ross, 1986). In tropical lakes these relationships had been described according to habitat heterogeneity (Genner et al., 1999; Sibbing \& Nagelkerke, 2001), seasonal patterns (Furse et al., 1979; Sampaio da Silva et al., 2005) and alteration processes (Lévêque, 1997; Piet, 1998). However, comparatively little information is available on how cooccurring fish utilize common resources during volume

${ }^{1}$ Centro Interdisciplinario de Investigación para el Desarrollo Integral Regional, Instituto Politécnico Nacional, Unidad Michoacán, Justo Sierra \#28 Jiquilpan, Michoacán 59510 México.rmoncayo@hotmail.com

${ }^{2}$ Laboratory of Limnology, Biology Department, Baylor University. One Bear Place \#97388, Waco, Texas 76798-7388 USA. Owen_Lind@baylor.edu 
change conditions, particularly those fish that belong to the zooplanktivorous fish guild in tropical shallow lakes.

Three endemic species of zooplanktivores are among the most abundant fish in lake Chapala, Mexico. Chirostoma jordani Woolman, 1894, C. labarcae Meek 1902, and C. consocium Jordan \& Hubbs, 1919 are atherinopsids that collectively constitute the lake's most important native fish fishery $(8 \%$ of the total capture in 2000, with a production of $266 \mathrm{t} \mathrm{year}^{-1}$ ) (INP, 2001). The life histories (Solórzano, 1963; Figueroa et al., 2003), distribution patterns (Moncayo-Estrada \& Buelna Osben, 2001), and diets (Navarrete et al., 1996; MoncayoEstrada et al., 2007) of individual Chirostoma species are well known, but interactions among species is not known for sympatric populations under different habitat conditions. The co-occurrence of these three similar species in lake Chapala suggests that some means of partitioning habitat and trophic resources must exist.

Lake Chapala is a warm, shallow, tropical lake with critical water fluctuations in the last decades (in millions of cubic meters: 4,817 in 1990; 3,519 in 1992; 4,209 in 1995; 1,991 in 2000; 5,286 in 2005) (CNA, 2006). Water volume fluctuations in Lake Chapala result from the combined action of a number of natural processes, particularly climatic variations, as well as human activities mainly related with agricultural and urban development in the watershed (Aparicio, 2001). Such extreme variability in lake volumes results in a highly variable spatial and temporal habitat availability patterns. We expected this habitat heterogeneity to impact on the trophic interactions among zooplanktivorous fish. As such we selected two extremes of lake water volume to examine the trophic interactions among fish in different lake habitats. The specific objectives of this study were (1) to investigate diet similarity among species at different lake sites, (2) to describe niche breadth and food overlap variation among species at critical shallow and volume recovery conditions and (3) to relate prey consumption patterns to zooplankton availability and determine planktivore prey preferences.

\section{Material and Methods}

\section{Study area}

Lake Chapala $\left(20^{\circ} 21^{\prime \prime} \mathrm{N} 103^{\circ} 26^{\prime \prime} \mathrm{W}\right)$ is the largest natural lake in Mexico (surface area of 90,000 ha) (Fig. 1). The lake has not been at capacity $\left(7,962\right.$ millions $\left.\mathrm{m}^{3}\right)$ since 1974 . Since then the lake has had a general decline in volume interrupted with periods of partial volume recovery (Lind \& DávalosLind, 2002). One low period ( $25 \%$ of the total lake volume, 1.5 $\mathrm{m}$ average depth and $2 \mathrm{~m}$ maximum depth) was in 2000 and a strong recovery episode ( $67 \%$ of the total lake volume, $4.1 \mathrm{~m}$ average depth and $8 \mathrm{~m}$ maximum depth) was in 2005 (CNA, 2006). The lake's recovery happened fast and was mainly related to hydrometheorological aspects than human initiatives. A "La Niña" event took place from 1997 to 2001 including dry years, scarce rains and low water flow to the lake, then an "El Niño" event was present from 2003 to 2004 including humid years, continuous and strong rains and high water flow to the lake. Even at capacity, the lake is very shallow, and, based on relative depth $(0.02 \%)$, it is possibly the world's largest shallow lake (Limón \& Lind, 1990). The lake's fish fauna include the endemic Atherinopsidae genus Chirostoma, endemic subfamily Goodeinae and native and endemic cyprinid fish species, as well as non-indigenous species, such as common carp Cyprinus carpio and tilapia Oreochromis niloticus (Moncayo-Estrada \& Buelna Osben, 2001).

\section{Data collection and analysis}

Fish and zooplankton collections were made simultaneously during August 2000 (low volume period) and August 2005 (recovery period) in two sites to examine potential spatial and inter-annual dietary shifts of the fish species. Specimens were incorporated to the fish collection at the Universidad Michoacana de San Nicolas de Hidalgo in Mexico (CPUM, registration key: MICH.-PEC-227-07-09). Catalog numbers: Chirostoma jordani, CPUM 5009 and CPUM 5042 for year 2000 and CPUM 5045 and CPUM 5048 for year 2005; C. labarcae, CPUM 5010 and CPUM 5043 for year 2000 and CPUM 5046 and CPUM 5049 for year 2005; C. consocium, CPUM 5011 and CPUM 5044 for year 2000 and CPUM 5047 and CPUM 5050 for year 2005. These sites were selected to represent different ecosystem conditions at the lake's opposite ends (Lind \& Dávalos-Lind, 1998; Lind et al., 2001) (Fig. 1). Both sites were located in the limnetic zone where preferential fish distribution, including all three species, and food availability were found. At the same time, these sites offered different limnological characteristics. In site 1 we found low flow conditions, higher depth and salinity and lower turbidity (in parentheses, respectively, depth, salinity and turbidity): year 2000 ( $1.5 \mathrm{~m}, 0.54 \mathrm{ppt}$ and $92 \mathrm{NTU})$ and year 2005 (4.2 m, $0.81 \mathrm{ppt}$ and $42.7 \mathrm{NTU}$ ). On the other hand, site $2 \mathrm{had}$ continuous circulation conditions because of the presence of the main affluent and effluent of the lake, represented a shallower zone with lower salinity and higher turbidity (in parentheses, respectively, depth, salinity and turbidity): year 2000 (0.4 m, $0.18 \mathrm{ppt}$ and $252.5 \mathrm{NTU})$ and year 2005 (2.6 $\mathrm{m}, 0.41 \mathrm{ppt}$ and 74.9 NTU). Finally, both sites had water in the low volume period, since the south shore usually dries up.

Samples were obtained during the day because a circadian cycle stomach analysis, not presented here, showed that these fish feed mainly in this time period. The fishing device was an experimental trawl net (length, $10 \mathrm{~m}$; depth $2 \mathrm{~m}$; mouth length $3 \mathrm{~m}$; mesh size $12 \mathrm{~mm}$ ) with a sampling time of $15 \mathrm{~min}$. Zooplankton densities were determined immediately before the fish collections by filtering $100 \mathrm{~L}$ of lake water with a



Fig. 1. Lake Chapala, Mexico. Numbers in bold represent the sampling sites, in italics depths contours (m). 
conical plankton net $(0.5 \mathrm{~m}$ ring diameter and $243 \mu \mathrm{m}$ mesh aperture), with $95 \%$ ethanol preservation. In the laboratory, for each specimen, standard length $(\mathrm{mm})$ and weight $(\mathrm{g})$ were recorded. Only fish $\geq 30 \mathrm{~mm}$ in length were examined, because of the difficulty to differentiate the species using individuals under such size. In general the size variation for the species was: Chirostoma consocium from 30 to $85 \mathrm{~mm} \mathrm{SL}$, C. labarcae from 44 to $70 \mathrm{~mm} \mathrm{SL}$ and $C$. jordani from 30 to $61 \mathrm{~mm} \mathrm{SL}$. The zooplankton samples were quantified by counting and classifying all individuals in three aliquots per site and per year.

Stomach contents were removed from all specimens as per Van Den Ayvle \& Roussel (1980). Prey items and zooplankton samples were identified to equivalent taxa level for quantitative analysis purposes. The frequency of prey taxa occurrence as a percentage of fish with non-empty stomachs, and each taxon's relative abundance, as a percentage of the total prey number, were computed according to Hyslop (1980). The index of relative importance expressed as percentages (IRI\%), was used to describe prey importance for comparison (Cortés, 1997). The volume measure as part of the \%IRI was quantitatively estimated through the Hynes Points Method (Hynes, 1950; Williams, 1981).

We used a multivariate approach to explore diet similarities among species (Liao et al., 2002). The units of comparison were the diets of each combination of species and sites between years. Logarithmic transformations of the $\%$ IRI values were used as input data. We tested the hypothesis of no diets differences between years using the non-metric MRPP (Multi-response Permutation Procedures) (McCune et al., 2002). As the input distance matrix we selected the Sørensen distance, with $n / \operatorname{sum}(n)$ as the weighting factor. MRPP (Mielke, 1984) provides a nonparametric multivariate test of differences between groups. Nonmetric MRPP is the same as MRPP except that the distance matrix is converted to ranks before calculating the test statistic. The A statistic from MRPP describes effect size, the "chance-corrected within-group agreement". When $\mathrm{A}=0$, the groups are no more or less different than expected by chance; when $\mathrm{A}=1$, all sample units are identical within each group. In community ecology $\mathrm{A}<0.1$ is common, even when differences between groups are apparent; $\mathrm{A}>0.3$ is fairly high (McCune et al., 2002). MRPP was performed using PC-ORD version 5.07 (McCune \& Mefford, 2006).

Levins' niche breadth $\left(\mathrm{B}_{\mathrm{i}}\right)$ (Krebs, 1999) was used to integrate the number of prey categories present and their relative proportion in the diet. Niche breadth classifies species as generalized feeders $\left(\mathrm{B}_{\mathrm{i}}>4.5\right)$, intermediate $\left(\mathrm{B}_{\mathrm{i}} 4.5\right.$ to 2.0$)$ and specialized feeders $\left(B_{i}<2\right)$ (Yap, 1988). Dietary overlap was assessed using two indexes to determine the intensity of the interaction between specie's pairs. Schoener's D index (Schoener, 1968) was selected because it is commonly used and its simplicity facilitates the interpretation of values obtained (Lecomte \& Dodson, 2005). In accordance with previous studies, a value of 0.6 was used as a threshold to delineate similar $(>0.6)$ from distinct feeding niches $(<0.6$; Smith \& Zaret, 1982). The Hurlbert index was also used to estimate overlap according to the way the species utilized each resource state in proportion to resource state abundance (Krebs, 1999). We used the abundance values (number) in the diet as well as in the zooplankton samples to calculate this index. The Hurlbert index assumes a value of zero when no resource state is shared by two species, a value of 1.0 when both species utilize each resource state in proportion to its abundance, and a value $>1.0$ if each species utilizes certain resource states more intensively than others and the utilization functions of the two species tend to coincide (Hurlbert, 1978).

Confidence intervals $\left(\mathrm{CI}_{95 \%}\right)$ of $\mathrm{B}_{\mathrm{i}}$ and $\mathrm{D}$ were obtained by means of the bootstrap method (Mueller \& Altenberg, 1985) by considering one thousand data re-samplings. The MannWhitney $U$-test was used with the breadth and overlap results to statistically compare values obtained within groups (sites in the same year) and between groups (different years) (Lecomte \& Dodson, 2005). The Mann-Whitney $U$-test was made using the statistical package SPSS for Windows (version 14.0; SPSS, Inc., Chicago, IL).

\section{Results}

\section{Diet composition}

Examination of 421 stomachs with $75 \%$ or more of fullness from the three species revealed six dominant prey taxa all related to the zooplankton community. A total of 241 fish were analyzed in August 2000, whereas 180 were analyzed in August 2005. Chirostoma consocium represented $43 \%$ of the fish analyzed (121 and 60, respectively), C.jordani represented 29\% (60 and 60 , respectively), and C. labarcae $29 \%$ (60 and 60, respectively). The most important prey taxa were cladocerans: Bosmina longirostris, Ceriodaphnia sp., Daphnia pulex, and Diaphanosoma brachyurum; and copepods: Cyclops sp. and Diaptomus sp. (Table 1). The rest of the food items were less frequent and included Rotifers, Hemipterans and fish prey. Two criteria were used to exclude these last food items from the analysis: First, they were present in only one species and, second, they represented less than $3 \%$ in the species diet.

According to the IRI\%, in general, Chirostoma jordani and C. labarcae diets were dominated by Bosmina longirostris and Daphnia pulex in 2000. Daphnia pulex was also present in $C$. consocium's diet in 2000 , however, the other dominant food items, that varied from site to site, were copepods. In 2005 Ceriodaphnia sp. dominated the diet of $C$. jordani, and D. brachyurum and $D$. pulex represented the second dominant prey in site 1 and 2, respectively. Chirostoma labarcae consumed Ceriodaphnia sp. and $D$. pulex in both sites, however, the dominance value was interchanged between sites (Table 1). The dominant food item in C. consocium varied from site to site in 2005 only coinciding with the important values of $D$. pulex in site 2 as compared with the other fish species (Table 1).

In the zooplankton samples, Diaptomus sp. was the dominant species in both, sites and years. However, the abundance of the rest of the prey varied between years with an increase in 2005. Diaphanosoma brachyurum was also abundant in all sites except site 2 in August 2000 where Bosmina 
longirostris had higher values. An important difference in zooplankton composition between years was the absence of Ceriodaphnia sp. in 2000 vs. an important proportion value in 2005. Bosmina longirostris had a more representative proportion in 2000 than 2005. In general Daphnia pulex and Cyclops sp. had low values in all sites, except site 2 in 2005 for $D$. pulex (Table 2).

In general, the expected difference in diets among the Chirostoma species when comparing years of contrasting conditions was supported by our MRPP results $(\mathrm{A}=0.22$, $\mathrm{p}<0.0001)$. In addition, a significant difference was detected when comparing sites in both years (MRPP analysis, $\mathrm{A}=0.17, \mathrm{p}=0.004$ ). A particular pair of groups (sites) can be compared using the same methods as the comparison across all groups. The pairwise comparisons show that sites 1 and 2 in the same year are broadly overlapping, and we cannot reject the null hypothesis (Table 3). The comparisons of sites between different years yielded statistics comparable to the overall comparisons (Table 3). Chirostoma labarcae had the most noticeable change in prey species proportion within the same taxon in site 1 at different years $(68.9 \%$ and $0 \%$ in $2000 ; 4.7 \%$ and $87.7 \%$ in 2005 , B. longirostris and Ceriodaphnia sp., respectively) (Table 2). Chirostoma consocium had the most important shift in the diet in site 2 when comparing both years. In general copepods dominated the diet regardless sites between years, except for this site (32.3\% and $19 \%$ in $2000 ; 3 \%$ and $84.3 \%$ in 2005, Cyclops sp. and D. pulex, respectively) (Table 2).

Table 1. Percentage by volume (V\%), frequency (F\%) and index of relative importance (IRI\%) for each zooplankton prey category, in the Lake Chapala and in the diet of C.jordani, C. consocium, and C. labarcae fish species.

\begin{tabular}{|c|c|c|c|c|c|c|c|c|c|c|}
\hline \multirow[b]{3}{*}{ Site } & \multirow[b]{3}{*}{ Prey } & \multicolumn{9}{|c|}{ August 2000} \\
\hline & & \multicolumn{3}{|c|}{ C.jordani } & \multicolumn{3}{|c|}{ C. consocium } & \multicolumn{3}{|c|}{ C. labarcae } \\
\hline & & $\mathrm{V} \%$ & $\mathrm{~F} \%$ & IIR $\%$ & $\mathrm{~V} \%$ & $\mathrm{~F} \%$ & IIR\% & $\mathrm{V} \%$ & $\mathrm{~F} \%$ & IRI\% \\
\hline \multirow{6}{*}{1} & Bosmina & 56.6 & 85.2 & 67.5 & 10.7 & 55.9 & 16.0 & 55.7 & 75 & 64.3 \\
\hline & Diaphar & 6.1 & 59.3 & 3.9 & 1.10 & 11.8 & 0.2 & 1.60 & 25 & 0.9 \\
\hline & Daphnia & 23.8 & 85.2 & 20.5 & 23.8 & 70.6 & 29.3 & 38.4 & 75 & 33.7 \\
\hline & Ceriodaph & 0 & 0 & 0 & 0 & 0 & 0 & 0 & 0 & 0 \\
\hline & Diap & 0 & 0 & 0 & 53.2 & 48.5 & 44.2 & 0 & 0 & 0 \\
\hline & $C y c$ & 12.5 & 63 & 8.1 & 11.6 & 39.7 & 10.3 & 4.3 & 33.3 & 1 \\
\hline & Bos & 17.3 & 50 & 19 & 13 & 26.4 & 14.6 & 16.9 & 35.3 & 43.5 \\
\hline & Diaphar & 9 & 33.3 & 5.8 & 2.3 & 15.1 & 1.8 & 7.4 & 17.6 & 7.8 \\
\hline & Daphnia & 36.8 & 76.7 & 43.8 & 26.3 & 37.7 & 34.9 & 21.6 & 47.1 & 45.8 \\
\hline & Ceri & 0 & 0 & 0 & 0 & 0 & 0 & 0 & 0 & 0 \\
\hline & Dia & 2.9 & 10 & 0.4 & 23.7 & 11.3 & 12.6 & 0 & 0 & 0 \\
\hline & & 34.1 & 56.7 & 31.2 & 34.6 & 26.4 & 36.1 & 3.4 & 17.6 & 2.9 \\
\hline \multirow{7}{*}{1} & & \multicolumn{9}{|c|}{ August 2005} \\
\hline & Bosmina & 15.1 & 100 & 17.4 & 4.3 & 90 & 4.9 & 2.6 & 76.5 & 4.1 \\
\hline & Diaphano & 21.7 & 100 & 21.6 & 12.4 & 100 & 13.5 & 0.1 & 17.6 & 0.0 \\
\hline & Daphnia & 7.4 & 100 & 7.1 & 10.4 & 100 & 13.2 & 5.1 & 70.6 & 6.3 \\
\hline & Cerio & 54.3 & 100 & 53.5 & 23.5 & 100 & 25.3 & 48.6 & 88.2 & 87.5 \\
\hline & Diap & 0.6 & 20 & 0.1 & 33.7 & 70 & 27.4 & 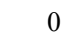 & , & 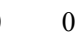 \\
\hline & Cyclops & 0.9 & 40 & 0.3 & 14.1 & 90 & 15.7 & 0 & 0 & 0 \\
\hline & Bosmina & 3.4 & 77.8 & 4.0 & 2.6 & 50 & 1.5 & 0 & 0 & 0 \\
\hline & Diaphan & 15.6 & 77.8 & 14.4 & 13.4 & 70 & 7.4 & 0.4 & 37.5 & 0.2 \\
\hline & Daphnia & 25.5 & 100 & 29.4 & 66.0 & 90 & 82.3 & 82.4 & 100 & 97.2 \\
\hline & Ceriodaphnia & 30.6 & 100 & 42.3 & 4.6 & 70 & 3.9 & 2 & 75 & 1.6 \\
\hline & Diaptomus & 0.7 & 33.3 & 0.4 & 6.2 & 50 & 2.5 & 0 & 0 & 0 \\
\hline & Cyclops & 6.7 & 66.7 & 5.1 & 7.2 & 40 & 2.5 & 0 & 0 & 0 \\
\hline
\end{tabular}

Chirostoma labarcae had the smallest average niche breadth value in all sites in both years $\left(\mathrm{B}_{i}=1.61\right)$ and was classified as specialized. Chirostoma jordani $\left(\mathrm{B}_{\mathrm{i}}=2.7\right)$ and C. consocium $\left(\mathrm{B}_{\mathrm{i}}=3.37\right)$ reached the intermediate feeders category. The most contrasting niche breath values occurred in 2005 at different sites. Chirostoma labarcae diet had fewer food items in site $2\left(\mathrm{~B}_{\mathrm{i}}=1.04\right)$ because of the preferential consumption of Daphnia pulex as consequence of prey availability, and a reduction in the Ceriodaphnia sp. and Bosmina longirostris consumption. Chirostoma consocium reached the generalized category in site 1 of the same year $\left(\mathrm{B}_{\mathrm{i}}=4.96\right)$ with similar values of all prey. Although in the intermediate category, Chirostoma jordani's niche breadth value increased from site 1 to site 2 in both years. The MannWhitney $U$-test showed no significant differences between the years $(\mathrm{p}=0.39)$ and between sites in the same year $(\mathrm{p}=0.28$ and $0.51,2000$ and 2005 respectively).

The comparison of the magnitude of niche overlap showed that the Chirostoma specie's average diet passed the threshold to delineate similar feeding niches in $2000(\mathrm{D}=0.64)$ as compared with $2005(\mathrm{D}=0.53)$, but no significant differences existed between years (Mann-Whitney $U$-test, $p=0.33$ ). In three contrasts out of six, the within-year overlap exceeded values of 0.6 in 2000; meanwhile, two out of six exceeded values of 0.6 in 2005 (Table 4). The capture region affected the overlap, and regular patterns appeared in both years: a higher $C$. jordani-C. labarcae overlap value was common in site 1 . In site 2 a higher $C$. jordani-C. consocium overlap value was found in 2000, and C. consocium-C. labarcae in 2005. The average higher overlap values between $C$. jordani and $C$. labarcae resulted because these fish consumed the same cladoceran prey in similar proportions.

When the proportion of the prey in the environment was included in the overlap analysis, a significant difference was found between years (Mann-Whitney $U$-test, $p=0.006$ ). Although the smallest value of the Hurlbert index is greater than 1 , this is expected because of the similar diets among the species (Table 3). The interpretation of the Hurlbert index is straightforward. For the interaction between Chirostoma jordani and C. consocium in 2005 the probability of interspecific encounter is $41 \%$ (or $1.41 \times$ ) higher than it would be if both species were uniformly distributed with respect to the abundance of the various resource states.

The significantly higher average overlap value found in 2000 as compared to 2005 (Hurlbert $=8.62$ and 2.32, respectively) indicated that the species use certain food items more intensively than others and the two species resource preferences tend to coincide (Table 4). A greater interaction was detected between Chirostoma consocium and C. labarcae because these fish consumed similar proportions of Daphnia pulex, and this prey was the most scarce in the lake (Hurlbert $=13.9$ in 2000). An ascending pattern in both year was found from site one to site two and a significant difference was found between sites in 2000 (Mann-Whitney $U$-test, $\mathrm{p}=0.05$ ). These results could be related with a distinct spatially horizontal gradient present in Lake Chapala 
Table 2. Percentage by number (N\%) for each zooplankton prey category, in the Lake Chapala and in the diet of Chirostoma jordani, C. consocium, and C. labarcae fish species.

\begin{tabular}{|c|c|c|c|c|c|c|c|c|}
\hline \multirow[b]{2}{*}{ Site } & \multicolumn{2}{|c|}{ Plankton } & \multicolumn{2}{|c|}{ C. jordani } & \multicolumn{2}{|c|}{ C. consocium } & \multicolumn{2}{|c|}{ C. labarcae } \\
\hline & Aug-00 & Aug-05 & Aug-00 & Aug-05 & Aug-00 & Aug-05 & Aug-00 & Aug-05 \\
\hline Bosmina & 17.5 & 4.8 & 72 & 19.4 & 19.5 & 5.2 & 68.9 & 4.7 \\
\hline Diaphanosoma & 29.8 & 29.8 & 4.4 & 21.1 & 1.1 & 11 & 3.9 & 0.2 \\
\hline Daphnia & 1.8 & 2.4 & 15.2 & 6.8 & 20.2 & 12.6 & 27 & 7.2 \\
\hline Ceriodaphnia & 0.01 & 19.0 & 0 & 51.6 & 0 & 20.6 & 0 & 87.7 \\
\hline Diaptomus & 47.4 & 41.7 & 0 & 0.7 & 43.3 & 34.3 & 0 & 0 \\
\hline Cyclops & 3.5 & 2.4 & 8.4 & 0.6 & 16 & 16.3 & 0.2 & 0 \\
\hline Bosmina & 19.6 & 6.6 & 26.9 & 5.5 & 14.2 & 2.3 & 48.5 & 0 \\
\hline Diaphanosoma & 11.4 & 25.7 & 11.4 & 16.8 & 3.4 & 3.9 & 16 & 0.6 \\
\hline Daphnia & 1.3 & 17.8 & 30.3 & 26 & 19 & 84.3 & 30.1 & 97.3 \\
\hline${ }^{2}$ Ceriodaphnia & 0.002 & 17.1 & 0 & 43.4 & 0 & 4.5 & 0 & 1.8 \\
\hline Diaptomus & 63.3 & 28.9 & 1.3 & 1.3 & 31 & 2 & 0 & 0 \\
\hline Cyclops & 4.4 & 3.9 & 30.2 & 6.7 & 32.3 & 3 & 5.3 & 0 \\
\hline
\end{tabular}

\section{Discussion}

Quantitative analysis of trophic relationships has focused on a fish assemblage's resource partitioning in different aquatic habitats (Ross, 1986), or streams and rivers wetlands (Lowe-McConnell, 1964; Zaret\& Rand, 1971; Prejs \& Prejs, 1987; Meschiatti, 1995; Mérona \& Mérona, 2004; Novakowski et al., 2008), but few analyses establish temporal habitat characteristics at interannual scales contrasting extreme conditions within ecosystems. Results from the present study show that volume change in shallow lakes -a critical low volume and a recovery period- greatly modifies the trophic interactions of closely related sympatric zooplanktivorous fish species with no apparent differences in their diets. When volume drops and species interact more, as in 2000, the trophic interaction increases importantly due to less segregation and less availability of the preferred prey. However, different interaction patterns between species pairs appear at distinct lake areas reflecting the heterogeneous prey taxa distribution, and other niche dimensions- such as spatial distribution, could promote partitioning. As the lake volume recovers, a reduction of niche overlap values reflects less contact among the species and more ready prey availability, probably as a consequence of the increasing transparency of the deeper lake (Echaniz et al., 2006; Castro et al., 2007).

Zooplanktivory behavior with few prey taxa have been documented extensively in the Atherinopsidae family (Gon \& Ben-Tuvia, 1983; Wurtsbaugh \& Li, 1985; Present \& Conover, 1992; Peck et al., 2003). Chirostoma species consumed six predominantly small-sized prey species, and cladocerans were the preferred food item. The high specialization level of the three species and prey abundance in the lake may explain the lack of dietary differentiation and an important niche overlap among populations in shallow conditions. Abundance patterns and interannual composition differences in zooplankton community influence Chirostoma diets (Navarrete et al., 1996; Moncayo-Estrada et al., 2007). However, in Lake Chapala Chirostoma species were feeding quite extensively in some sites on Bosmina longirostris and Daphnia pulex, although contemporaneous plankton samples yielded low abundance, as compared with other prey species. It is noteworthy that Diaptomus sp. was not eaten, even though it was the most abundant plankton species. This diet pattern could be a function of prey selection by Chirostoma because of high number of species interacting, predator avoidance and small size by Diaptomus sp. (Gilmurray \& Daborn, 1981).

Superimposing an intermediate and specialized feeding on a relatively homogeneous prey field will invariably yield low differences among samples collected in distinct areas. Levin's niche breadth estimates revealed an impressive withinyears and between-years homogeneity in the diets. Individual fish fed homogenously on a few prey categories between sites within a specific year. The shoaling behavior of Chirostoma species may explain such an observation (Moncayo-Estrada \& Buelna-Osben, 2001). As in the case of the smelt, Osmerus mordax (Lecomte \& Dodson, 2005), the 'forage-area copying' concept (Pitcher \& House, 1987) could apply to the Chirostoma species analyzed. This concept proposes that members of a shoal will start feeding after seeing some members foraging. Thus, upon locating an abundant prey aggregation, all individuals of a shoal might start feeding and would consequently have similar gut contents.

Similarly, intermediate and specialized feeding translates into high dietary niche overlap (i.e., similar niche) even for within and between-year comparisons. Incorporating sources of variance to compare diet overlap allowed the significance of the calculated niche overlap indices to be calculated (Lecomte $\&$ Dodson, 2005). To add statistical validity to the niche overlap, different authors have used a bootstrap approach to estimate confidence intervals around the mean overlap values or conducted simulations to estimate error (Smith \& Zaret, 1982; Mueller \& Altenberg, 1985). In the present case, the use of 0.6 as the threshold separating similar from dissimilar diets could be inappropriate as the species have closely related diets. In addition, at this value the confidence intervals were broad \pm 0.25 and the lower limit was smaller than 0.6 (C.jordani-C. labarcae in site 1 of 2005 with mean 0.64 and intervals 0.38 0.88 ). A better threshold value was 0.79 because the confidence intervals narrowed to \pm 0.06 (C. jordani-C. consocium site 2 of 2000 with mean 0.79 and intervals $0.73-0.85$ ).

In natural systems where diet is influenced by multiple sources of variation, the incorporation of an alternative niche overlap index like the Hurlbert index, where the proportion of 
Table 3. Summary statistics for the Multi-response Permutation Procedure. Results are given for the analysis of sites (1 and 2), comparing across all groups, as well as multiple pairwise comparisons for the Sørensen distances. $A$ is the chance-corrected within-group agreement and $P$ is the probability.

\begin{tabular}{ccccccc}
\hline & 2000 & 2005 & \multicolumn{4}{c}{$2000 \times 2005$} \\
\cline { 2 - 7 } & Site 1 x 2 & Site 1 x 2 & Site 1 & Site 2 & Site 1 x 2 & Site 2 x 1 \\
\hline$A$ & -0.07 & 0.04 & 0.15 & 0.21 & 0.2 & 0.15 \\
$P$ & 0.9 & 0.22 & 0.007 & 0.006 & 0.003 & 0.01 \\
\hline
\end{tabular}

prey in the environment is considered, is important to corroborate results (Krebbs, 1999). The interpretation of the results about the difference between years can be interpreted as follows: in years 2000 and 2005 the species have identical utilization functions both favoring the less common resource states, so that the index value exceeds 1.0. However, in 2000 the species utilization functions were more than canceled by the now greater intensity with which the different interactions utilized the less common resource states; and so the Hurlbert value exceed 1.0 by an even greater amount than it did for year 2005 .

In the present study, the inclusion of two years with contrasting habitat conditions reinforces the conclusion of Coops et al. (2003) that water-level fluctuations have an overriding effect on the biota's ecology. The simplest possible effect of water level fluctuation on the fish community of a shallow lake is described as a change in population density due to change in water volume ('concentration' effect) $(\mathrm{FAO} /$ UNDP, 1970; Blake, 1977; Ita, 1978). This effect is more accentuated when drawdown reduces water volume by $>55 \%$ (Bernacsek, 1984). In 2000, a $3 \mathrm{~m}$ drawdown reduced lake Chapala volume by $80 \%$ increasing fish relative abundance (0.88). Conversely, a water level increase of $2.17 \mathrm{~m}$ in 2005 resulted in a volume increase of $50 \%$ and in a decrease in fish relative abundance (0.12). In addition, high water levels create inundated areas that fish may utilize (Keith, 1975), whereas low water surface levels may limit fish movements, available habitat, or degrade water quality (Bennett et al., 1995; Heggenes et al., 1996). In the trophic sense, fish bioaccumulation has been related to changes in feeding strategies according to high and low water seasons in the tropics (Sampaio da Silva, 2005; Bastos et al., 2007)

Water level fluctuations promote an increase in turbidity, which could affect trophic relations at the pelagic level (James \& Graynoth, 2001; Castro et al., 2007). Turbidity, due to resuspension, has been increasing over the time in relation to water level fluctuations of Lake Chapala (Limón \& Lind, 1990). An increase in turbidity could be more beneficial for planktivorous fish because their encounter rates with piscivorous predators are reduced more than their encounter rates with their planktonic prey (Utne, 1997; Vogel \& Beauchamp, 1999; De Robertis et al., 2003). This is similar to fog, which has little effect on short-range vision but can greatly diminish the visibility of objects at a distance (Lythgoe, 1979), which also supports the "turbidity as cover" hypothesis (Gregory, 1993; Aksnes \& Utne, 1997; Gadomski \& Parsley, 2005).
Table 4. Values of the Schoener (D) and Hurlbert niche overlap indexes. Cjor $=$ Chirostoma jordani, Ccon $=$ C. consocium and $C l a b=C$. labarcae.

\begin{tabular}{llcccc}
\hline \multirow{2}{*}{ Site } & Interaction & $\mathrm{D}$ & Hurlbert & $\mathrm{D}$ & Hurlbert \\
\cline { 3 - 6 } 1 & Cjor-Ccon & 0.43 & 3.63 & 0.51 & 1.41 \\
& Cjor-Clab & 0.88 & 5.30 & 0.64 & 1.58 \\
& Ccon-Clab & 0.49 & 5.55 & 0.36 & 2.85 \\
\hline \multirow{2}{*}{2} & Cjor-Ccon & 0.79 & 12.6 & 0.50 & 1.65 \\
& Cjor-Clab & 0.73 & 10.7 & 0.36 & 4.55 \\
& Ccon-Clab & 0.52 & 13.9 & 0.84 & 1.88 \\
\hline
\end{tabular}

Chesson (1990) and Abrams (1999) found that temporal fluctuations in environmental conditions had an important effect on the coexistence of closely related species. The species interaction regarding limited food resources is seen by Lecomte \& Dodson (2005) as a potent mechanism favoring the divergence and coexistence of sympatric populations. Although trophic segregation was low in 2000, competing species could coexist if mechanisms were present that effectively increased the number of resources presented and/ or allowed populations to exhibit stable cyclic behavior (Richards et al., 2000). Examples include resource partitioning of the same food items (Haigh \& Smith, 1972; Schoener, 1974) such as the differential consumption of plankton prey by the different Chirostoma species.

Ross (1986) determined that a high level of separation among coexisting sympatric species occurred along at least one of three resource dimensions (food, habitat and time). The exploitation of distinct habitats exhibiting divergent ecological characteristics is as effective as maintaining sympatric populations within an ecosystem setting without diet differentiation (Tilman, 1994). In 2000, the spatial segregation of the three species was observed to be a function of habitat characteristics (principally depth and salinity) (Moncayo-Estrada \& Lind, unpubl. data). When local abundance was high, Chirostoma jordani individuals dominated the east shallow shore, whereas the C. consocium individuals dominated the central shallow areas of the lake and $C$. labarcae the deepest zone. This observation raises the possibility that in other ecosystem settings, spatial segregation may precede diet segregation ( $c f$., Lecomte \& Dodson, 2005).

Differences in abundance and community indices among years had been detected commonly at sites with higher waterlevel variability (Rogers et al., 2000) which in Lake Chapala is related to the site 1 . However, lake morphometry per se did not explain significantly the variation in the population characteristics because other variables, such as physical factors, food resources and species interactions also influence the functional structure of the fish community (Tomcko \& Pierce, 2001; Hölker \& Breckling, 2005). The pattern revealed by niche overlap from one end to the other of the lake was related to the distinct spatial (east-west) gradient described before for physical (turbidity and Secchi depth) and biological characteristics (phytoplankton production and Chlorophyll $a$ concentration) (Lind et al., 1992). 
In general, the trophic interactions in the zooplanktivorous guild were closely related to the volume change in shallow Lake Chapala. A critical low volume level caused a complex significant interaction among the species because of low fish segregation and prey availability. Different strategies were identified that promoted partitioning, including differential use of food items, and regular overlap patterns at different sites. In addition, another dimension of niche interacted to avoid competition, the differential distribution relative to a distinct spatial gradient of environmental factors such as depth and salinity. Given the numerical importance of the Chirostoma species as part of nektonic assemblages, observations on the trophic spectrum of these and other species can help to generate a conceptual model of the trophic webs and dynamics of the feeding relations among communities found in shallow lakes.

\section{Acknowledgements}

We thank J. Morales Castellanos, Ma.V. Segura García, Salvador González, I. Aguilera Taylor and Omar E. Gonzalez Sandoval for extremely helpful support in field and lab work. We also thank Carlos Lopez for help on zooplankton identification. The research upon which this paper is based was supported by SIMORELOS-CONACYT (19980306009), CEGEPI-IPN (970468), Bob Gardner Memorial Grant Award and Jack and Norma Folmar Endowment Fund Research Award from Baylor University, and The Explorers Club Research Award. R. M. E. and C. E. G. are supported by COFAA - Comisión de Operación y Fomento de Actividades Académicas - and EDI Estímulo al Desempeño Académico.

\section{Literature Cited}

Abrams, P. A. 1999. Is predator mediated coexistence possible in unstable systems? Ecology, 80(2): 608-621.

Aparicio, J. 2001. Hydrology of the watershed. Pp. 1-25. In: Hansen, A. M. \& M. van Afferden (Eds.). The Lerma-Chapala Watershed. Evaluation and Management. Kluwer Academic, New York, 385p.

Bastos, W. R., R. de Almeida, J. G. Dórea \& A. C. Barbosa. 2007. Annual flooding and fish-mercury bioaccumulation in the environmentally impacted Rio Madeira (Amazon). Ecotoxicology, 16: 341-346.

Bennett, W. A., D. J. Ostrach \& D. E. Hinton. 1995. Larval striped bass condition in a drought-stricken estuary: evaluating pelagic food-web limitation. Ecological Applications, 5: 680-692.

Bernacsek, G. M. 1984. Guidelines for dam design and operation to optimize fish production in impounded river basins (based on a review of the ecological effects of large dams in Africa). FAO CIFA Technical Paper, 11: 1-98.

Castro, B. B., S. M. Marques \& F. Gonçalves. 2007. Habitat selection and dial distribution of the crustacean zooplankton from a shallow Mediterranean lake during the turbid and clear water phases. Freshwater Biology, 52(3): 421-433.

Carvalho, J. C. \& P. Gomes. 2004. Feeding resource partitioning among four sympatric carnivores in the Peneda-Gerês National Park (Portugal). Journal of Zoology, 263(3): 275-283

Chesson, P. 1990. Geometry, heterogeneity and competition in variable environments. The Royal Society of London B, Biological Sciences, 330: 165-173.
Coops, H., M. Beklioglu \& T. L. Crisman. 2003. The role of waterlevel fluctuations in shallow lake ecosystems - workshop conclusions. Hydrobiologia, 506(1): 23-27.

Cortés, E. 1997. A critical review of methods of studying fish feeding based on analysis of stomach contents: application to elasmobranch fishes. Canadian Journal of Fisheries and Aquatic Sciences, 54(3): 726-738.

Echaniz, S. A., A. M. Vignatti, S. J. de Paggi, J. C. Paggi \& A. Pilati. 2006. Zooplankton seasonal abundance of South American saline shallow lakes. International Review of Hydrobiology, 91(1): 86-100.

Emery, A. R. 1973. Comparative ecology and functional osteology of fourteen species of damselfish (Pisces: Pomacentridae) at Alligator Reef, Florida Keys. Bulletin of Marine Science, 23(3): 649-770.

Figueroa, L. G., J. Paulo \& M. C. Hernandez. 2003. Retrospectiva y avances en el conocimiento de la biología y ecología de los charales y pescados blancos del género Chirostoma (Atheriniformes:Atherinopsidae). Pp. 29-48. In: Rojas, P. M. \& D. Fuentes (Eds.). Historia y avances del cultivo de pescado blanco. Instituto Nacional de la Pesca-Secretaría de Agricultura, Ganadería, Desarrollo Rural, Pesca y Alimentación, México. 254p.

Furse, M. T., R. G. Kirk, P. R. Morgan \& D. Tweddle. 1979. Fishes: distribution and biology in relation to changes. Pp. 175-208. In: Kalk, M., A. J. McLachlan \& C. Howard-Williams (Eds.). Lake Chilwa, studies of change in a tropical ecosystem. Dr. W. Junk Publishers, The Netherlands. Monographic Biology, 35. 227p.

Genner, M. J., G. F. Turner \& S. J. Hawkins. 1999. Foraging of rocky habitat cichlid fishes in Lake Malawi: coexistence through niche partitioning? Oecologia, 121(2): 283-292.

Gilmurray, M. C. \& G. R. Daborn. 1981. Feeding relations of the Atlantic silverside Menidia menidia in the Minas Basin, Bay of Fundy. Marine Ecology Progress Series, 6: 231-235.

Gon, O. \& A. Ben-tuvia. 1983. The biology of Boyer's sand smelt, Atherina boyeri Risso, in the Bardawill Lagoon on the Mediterranean coast of Sinaí. Journal of Fish Biology, 22(5): 537-547.

Haigh, J. \& J. M. Smith. 1972. Can there be more predators than prey? Theoretical Population Biology, 3(3): 290-299.

Heggenes, J., S. J. Saltveit \& O. Lingaas. 1996. Predicting fish habitat use to changes in water flow: modelling critical minimum flows for Atlantic salmon, Salmo salar, and brown trout, S. trutta. Regulated Rivers-Research \& Management, 12(2-3): 331-344.

Hölker, F. \& B. Breckling. 2005. A spatiotemporal individual-based fish model to investigate emergent properties at the organismal and the population level. Ecological Modeling, 186(4): 406-426.

Hurlbert, S. H. 1978. The measurement of niche overlap and some relatives. Ecology, 59(1): 67-77.

Hynes, H. B. N. 1950. The food of freshwater sticklebacks (Gasterosteus aculeatus and Pygosteus pungitius) with a review of methods used in studies of the food of fishes. Journal of Animal Ecology, 19(1): 36-58.

Hyslop, E. J. 1980. Gut contents analysis - a review of methods and their application. Journal of Fish Biology, 17(4): 411-429.

INP (Instituto Nacional de la Pesca) (National Fisheries Institute). 2001. Anuario pesquero 2000. Instituto Nacional de la Pesca-Secretaría de Medioambiente Recursos Naturales y Pesca, México, 97p.

James, G. \& E. Graynoth. 2001. Variable lake levels and water clarity: how do they affect trout populations? Water \& Atmosphere, 9(1): 26-27.

Keith, W. E. 1975. Management by water level manipulation. Pp. 489-497. In: Clepper, H. (Ed.). Black bass biology and management. Sport Fishing Institute: Washington, DC, 534p.

Krebs, C. J. 1999. Ecological Methodology. Benjamin Cummings, New York, 654p. 
Kuroda, M., K. Wada \& M. Kamada. 2005. Factors influencing coexistence of two brachyuran crabs, Helice tridens and Parasesarma plicatum, in an estuarine salt marsh, Japan. Journal of Crustacean Biology, 25(1): 146-153.

Lecomte, F. \& J. J. Dodson. 2005. Distinguishing trophic and habitat partitioning among sympatric populations of the estuarine fish Osmerus mordax Mitchill. Journal of Fish Biology, 66(6): 16011623.

Lévêque, C. 1997. Biodiversity dynamics and conservation: The freshwater fish of Tropical Africa. Cambridge University Press, New York, 451p.

Liao, H., C. L. Pierce \& J. G. Larscheid. 2002. Diet dynamics of the adult piscivorous fish community in Spirit Lake, Iowa, USA 1995-1997. Ecology of Freshwater Fish, 11(3): 178-189.

Limón, J. G. \& O. T. Lind. 1990. The management of Lake Chapala (Mexico): Considerations after significant changes in the water regime. Lake Reservoir Management, 6(1): 61-70.

Lind, O. T. \& L. Dávalos-Lind. 2002. Interaction of water quantity with water quality: The Lake Chapala example. Hydrobiologia, 467(1-3): 159-167.

Lind, O. T., R. D. Doyle, D. S. Vodopich, B. G. Trotter, J. G. Limón \& L. Dávalos-Lind. 1992. Clay turbidity: Regulation of phytoplankton production in a large, nutrient-rich tropical lake. Limnology and Oceanography, 37(3): 549-565.

Lowe-McConnell, R. H. 1964. The fishes of the Rupununi savanna district of British Guiana, South America. Part 1. Ecological grouping of fish species and effects of the seasonal cycle on the fish. Journal of the Linnean Society (Zoology), 45(304): 103-144.

Malmquist, H. J. 1992. Phenotypic-specific feeding behavior of two arctic charr Salvelinus alpinus morphs. Oecologia, 92(3): 354-361.

McCune, B. \& M. J. Mefford. 2006. PC-ORD: Multivariate analysis of ecological data. Version 5.07. MjM Software Design, Gleneden Beach, Oregon, USA.

McCune, B., J. B. Grace \& D. L. Urban. 2002. Analysis of ecological communities. MjM Software Design, Gleneden Beach, Oregon, USA, 300p.

Meschiatti, A. J. 1995. Alimentação da comunidade de peixes de uma lagoa marginal do rio Mogi Guaçu, SP. Acta Limnologica Brasiliensia, 8: 115-137.

Mérona, B. \& J. R. Mérona. 2004. Food resource partitioning in a fish community of central Amazon floodplain. Neotropical Ichthyology, 2(2): 75-84.

Mielke, P. W. \& H. K. Iyer. 1982. Permutation techniques for analyzing multi-response data from randomized block experiments. Communications in Statistics - Theory and Methods, 11(13): 1427-1437.

Moncayo-Estrada, R. \& H. R. Buelna-Osben. 2001. Fish fauna of Lake Chapala. Pp. 215-242. In: Hansen, A. M. \& M. van Afferden (Eds.). The Lerma-Chapala Watershed. Evaluation and Management. Kluwer Academic, New York, 385p.

Moncayo-Estrada, R., C. Escalera-Gallardo, C. Lopez \& O. T. Lind. 2007. Diet of Chirostoma lucius (Pisces: Atherinomorpha): seasonal trophic spectrum and ontogeny of piscivory. The Southwestern Naturalists, 52(2): 229-233.

Mueller, L. D. \& L. Altenberg. 1985. Statistical inference on measures of niche overlap. Ecology, 66(4): 1204-1210.

Navarrete, N. A., R. Sánchez \& M. L. Rojas. 1996. Selección del zooplancton por el charal Chirostoma jordani (Atheriniformes: Atherinidae). Revista de Biología Tropical, 44(1): 1-9.

Novakowski, G. C., N. S. Hahn \& R. Fugi. 2008. Diet seasonality and food overlap of the fish assemblage in a pantanal pond. Neotropical Ichthyology, 6(4): 567-576.
Peck, M. A., R. S. Katersky, L. M. Menard \& D. A. Bengtson. 2003. The effect of body size on food consumption, absorption efficiency, respiration, and ammonia excretion by the inland silverside, Menidia beryllina (Cope) (Osteichthyes: Atherinidae). Journal of Applied Ichthyology, 19(4): 195-202.

Piet, G. J. 1998. Impact of environmental perturbation on a tropical fish community. Canadian Journal of Fisheries and Aquatic Sciences, 55(8): 1842-1853.

Pitcher, T. J. \& A. C. House. 1987. Foraging rules for group feeders: area copying depends upon food density in shoaling goldfish. Ethology, 76(2): 161-167.

Prejs, A. \& K. Prejs. 1987. Feeding of tropical freshwater fishes: seasonality in resource availability and resource use. Oecologia, 71(3): 397-404.

Present, T. M. C. \& D. O. Conover. 1992. Physiological basis of latitudinal growth differences in Menidia menidia: variation in consumption or efficiency? Functional Ecology, 6(1): 23-31.

Richards, S. A., R. M. Nisbet, W. G. Wilson \& H. P. Possingham. 2000. Grazers and diggers: exploitation competition and coexistence among foragers with different feeding strategies on a single resource. The American Naturalists, 155(2): 266-279.

Rogers, M. W., M. S. Allen \& M. D. Jones. 2005. Relationship between river surface level and fish assemblage in the Ocklawaha River, Florida. River Research and Applications, 21(5): 501-511.

Ross, S. T. 1986. Resource partitioning in fish assemblages: A review of field studies. Copeia, 1986(2): 352-388.

Schoener, T. W. 1968. The anolis lizards of Binimi: Resource partitioning in a complex fauna. Ecology, 49(4): 704-726.

Schoener, T. W. 1974. Resource partitioning in ecological communities. Science, 185(4145): 27-39.

Sampaio da Silva, D., M. Lucotte, M. Roulet, H. Poirier, D. Mergler, E. Oliveira Santos \& M. Crossa. 2005. Trophic structure and bioaccumulation of mercury in fish of three natural lakes of the Brazilian Amazon. Water, Air \& Soil Pollution, 165: 77-94.

Sibbing, F.A. \& L. A. J. Nagelkerke. 2001. Resource partitioning by Lake Tana barbs predicted from fish morphometrics and prey characteristics. Reviews in Fish Biology and Fisheries, 10(4): 393-437.

Smith, E. P. \& T. M. Zaret. 1982. Bias in estimating niche overlap. Ecology, 63(5): 1248-1253.

Solórzano, P.A. 1963. Algunos aspectos biológicos del pescado blanco del Lago de Pátzcuaro, Mich. Dirección General de Pesca, México, 25p.

Tilman, D. 1994. Competition and biodiversity in spatially structured habitats. Ecology, 75(1): 2-16.

Tomcko, C. M. \& R. B. Pierce. 2001. The relationship of bluegill growth, lake morphometry, and water quality in Minnesota. Transactions of the American Fisheries Society, 130(2): 317-321.

Van Den Avyle, M. J. \& J. E. Roussel. 1980. Evaluation of a simple method for removing food items from live black bass. Progressive Fish Culturists, 42(4): 222-223.

Williams, M. J. 1981. Methods for analysis of natural diet in portunid crabs (Crustacea: Decapoda). Journal of Experimental Marine Biology and Ecology, 52(1): 103-113.

Wurtsbaugh, W. \& H. Li. 1985. Diel migrations of a zooplanktivorous fish (Menidia beryllina) in relation to the distribution of its prey in a large eutrophic lake. Limnology and Oceanography, 30(3): 565-576.

Yap, S. Y. 1988. Food resource utilization partitioning of fifteen fish species at Bukit Merah Reservoir, Malaysia. Hydrobiologia, 157(2): 143-160.

Zaret, T. M. \& A. S. Rand. 1971 Competition in tropical stream fishes: support for the competitive exclusion principle. Ecology, 52(2): 336-342.

Accepted November 9, 2010 Published March 31, 2011 